\title{
Soil degradation in Kerala state and a case study on socio-economic impact due to flood in its Idukki district
}

\author{
P. Sreepriya* \\ Department of Agricultural Economics, Tamil Nadu Agricultural University, Coimbatore- \\ 641003 (Tamil Nadu), India \\ R. Balasubramanian \\ Agricultural College and Research Institute Vazhavachanur, Tamil Nadu Agricultural Uni- \\ versity, Thiruvanamalai-606753 (Tamil Nadu)
}

*Corresponding author. E-mail: sreepriya.padmaja@gmail.com

\begin{abstract}
Land degradation is the reduction of the biological or economic productivity of cropland, pasture, forest, and woodlands of which soil degradation is the major contributor. The present study was undertaken to understand the type and degree of major type of soil degradation, viz soil erosion and acidity in Kerala and to study the socio-economic impact of the flood on individual households in Idukki district during 2018. Random sampling was undertaken with a total sample of 180 households from different occupational background for the case study. Various studies conducted in pre-flood period revealed that in Kerala, $94.7 \%$ of the total geographical area were acidic and $71.28 \%$ were eroded, whereas in Idukki $96.3 \%$ of the total geographical area is acidic and $80 \%$ were eroded. United Nations post-disaster need assessment report has estimated a total economic loss of Rs.31,000 crores in Kerala due to flood. Agricultural sector (Rs 3646 crores), fisheries (Rs 93.72 crores), forestry (Rs 9.55 crores), infrastructure, power, housing and tourism sector (Rs 2000 crores) also suffered economic losses post-flood in Kerala. The case study in Idukki district revealed that average damage cost of individuals due to flood with different occupational status was Rs.13.36 lakhs with relative damage cost of $364 \%$. As farmers are reluctant to undertake soil conservation activities due to high labour costs and capital-intensive plantation crops, public investment has to be strengthened conservation of natural resources of flood-affected areas of Kerala.
\end{abstract}

Keywords: Damage cost, Floods, Socio-Economic impacts, Soil degradation

\section{INTRODUCTION}

Land degradation is a composite term covering the many ways in which quality and productivity of land may diminish from the point of view of the land user and of society at large (Stocking and Murnaghan, 2001). Land degradation leads to the reduction of the biological or economic productivity of croplands, forests, pastures etc. Out of 5 billion ha ( $43 \%$ of earth's vegetated surface) of the total degraded land, soil degradation is responsible for 2 billion hectares mainly through wind and water erosion. Soil degradation is the deterioration of the physical, chemical (nutrient depletion) and biological properties (reduction in soil organic matter, biomass carbon and diversity of soil fauna) of soil resulting in soil compaction, salinisation, acidification, and soil loss from wind and water erosion (FAO, 2019).

The biggest share of the total annual costs of land degradation by land use and land cover change in India is contributed by Kerala, Rajasthan, Andhra Pradesh, Orissa and Madhya Pradesh, whereas

\section{Article Info}

https://doi.org/10.31018/

jans.vi.2265

Received: April 28, 2020

Revised: May 15, 2020

Accepted: May 23, 2020

\section{How to Cite}

Sreepriya, P. and Balasubramanian, R. (2020). Soil degradation in Kerala state and a case study on socio-economic impact due to flood in its Idukki district. Journal of Applied and Natural Science, 12(2): $159-164$. https://doi.org/10.31018/ jans.vi.2265 
Studies on the impact of flood in the state have mainly concentrated on the macro scenario with the estimation of losses in different sectors like agriculture, infrastructure, livelihood, tourism, etc. and these studies have not focussed on more localised socio-economic impacts. The present study was carried out to compile data on soil degradation, especially soil acidity and erosion from various sources for Kerala. The study also indented to document sectoral wise losses of floods in Kerala and to undertake a case study to understand the socio-economic impact of the flood on individual households under different occupational and income status in Idukki district. The analysis may help in more effective post-flood rehabilitation and support on the basis of relative damage to individuals in the scenario of repeated flood and related degradation.

\section{MATERIALS AND METHODS}

The present study was an attempt to compile data on soil degradation especially soil acidity and soil erosion in Kerala from various secondary sources such as Kerala State Disaster Management Authority (KSDMA), and Department of Soil Survey and Soil Conservation (DSSC) of Government of Kerala (GoK), NBSS and LUP (ICAR). Percentage of the area under different erosion and acidic classes to the total geographical area have been worked out and presented. The soil health status of Kerala post-flood of 2018 has been studied by DSSC (GoK, 2018a) under the report titled "Soil Health Status of Kerala in Post Flood Scenario". The case study was conducted in Idukki district $\left(9^{\circ} 51^{\prime} 0 " \mathrm{~N}, 76^{\circ} 58^{\prime} 0.01 " \mathrm{E}\right)$, known as spice garden of Kerala, which lies in the Western Ghats of Kerala. It is the second-largest district in the area $(5,10,500 \mathrm{ha})$ accounting for $11.23 \%$ of the total area of the state but has the lowest population density $(3.7 \%)$. More than half of the district is covered by forests where urban areas are densely populated, and villages are sparsely populated. Lowland, midland, midland, upland, highland and mountainous regions are the physiographic divisions identified in the district with a major portion lying in upland and highland. Idukki received $66 \%$ more rainfall during the southwest monsoon season of 2018. Devikulam, Udumbanchola, Idukki and Thodupuzha were the affected taluks of which, Devikulam and Idukki taluks were the worst affected (GoK, 2018a).

A primary survey was conducted in one of the worst affected area, Cheruthoni in Vazhathope village in Idukki taluk during November 2018 along with focus group discussions with the officials of Krishi Bhavans and Department of Soil Survey and Soil Conservation, Govt of Kerala. Cheruthoni was affected by flooding, landslides and dam opening leading to loss of lives, public infrastructure, houses and other buildings, planta- tion, horticulture and spice crops. Random sampling was undertaken with a total sample of 180 households from different occupational background, of which $70 \%$ were involved in agricultural activities. Diversification in occupation mentioned in the discussion meant occupational diversification among the sampled individuals viz, farming, farming and non-farming, farming and service, non-farming and service sectors. The primary survey was conducted using interview schedule covering the general characteristics of the household, income details, damage to agriculture, household assets or inventories, damage to house structure, income loss, business loss and repair and recovery costs etc., perception of the adequacy of warning, adoption of insurance, perception towards shifting of residence post floods etc.

The relative disaster loss was also calculated to understand the extend and impact of damage caused to individuals of different income status (Annual income in Rs)). Absolute disaster loss or cost involves damage to agriculture, household assets or inventories, damage to house structure, income loss, business loss and repair and recovery costs.

\section{Relative disaster loss $=\frac{\text { Absolute Disaster loss }}{\text { Annual average income }}$}

(De Silva and Kawasaki, 2018)

Income generation during post-flood was considered to make an analysis with the occupational status of the individuals. Income generation postflood in the months of September and October were considered and compared with the average monthly income pre-flood.

\section{RESULTS AND DISCUSSION}

Status of the soil before the flood in Kerala state including district Idukki: The study indicated that before the flood of 2018 in Kerala that the total geographical area of Kerala was $38,86,300$ ha and that of Idukki district was 5,10,500 ha. A study conducted by Majji et al. (2012) has reported that in Kerala, $94.7 \%$ of the soil of the total geographical area was acidic, whereas $71.8 \%$ was under moderately acidic category (Table 1). In Idukki, with large forest cover and forest soils in the state being acidic, $96.2 \%$ of the total area was acidic, whereas $86.25 \%$ of the area was under moderately acidic category and $9.68 \%$ area was strongly acidic. In 2012, Idukki had the most area under acidic soils in the state $(12.9 \%$ of the total geographical area of Kerala), which was mainly moderately to strongly acidic (Table 1). Kerala and Himachal Pradesh ranked highest in acidic soils in India, i.e. more than $90 \%$ of total geographical area (NBSS and LUP, 2014).

In Kerala, $71.28 \%$ of the total geographical area 
Sreepriya, P. and Balasubramanian, R. / J. Appl. \& Nat. Sci. 12(2): 159 - 164 (2020)

Table 1. Distribution of Acid Soils in Idukki and Kerala as in 2012 (Source: Majji et al., 2012).

\begin{tabular}{lllll}
\hline Category & $\begin{array}{l}\text { Area (in '000ha)- } \\
\text { Kerala }\end{array}$ & $\begin{array}{l}\text { \% to Total } \\
\text { Geographic area }\end{array}$ & $\begin{array}{l}\text { Area (in '000ha)- } \\
\text { Idukki }\end{array}$ & $\begin{array}{l}\text { \% to Total } \\
\text { Geographic area }\end{array}$ \\
\hline Strongly acidic & 138.0 & 3.6 & 49.4 & 9.68 \\
Moderately acidic & 2789.6 & 71.8 & 440.3 & 86.25 \\
Slightly acidic & 753.2 & 19.4 & 1.6 & 0.31 \\
Non acidic & 115.8 & 3.0 & 9.1 & 1.78 \\
Others & 89.8 & 2.3 & 10.1 & 1.98 \\
Total & 3886.3 & & 510.5 & \\
\hline
\end{tabular}

Table 2. Area under different soil loss classes in Kerala and Idukki as in 2014 (Source: NBSSandLUP, 2014).

\begin{tabular}{lllllll}
\hline SI.No & $\begin{array}{l}\text { Soil loss } \\
\text { (t/ha/yr.) }\end{array}$ & Erosion class & $\begin{array}{l}\text { Area (in ha) } \\
\text { Kerala }\end{array}$ & \% to TGA & $\begin{array}{l}\text { Area (in ha)- } \\
\text { ldukki }\end{array}$ & \% to TGA \\
\hline 1 & $<5$ & Slight & 1920510 & 49.8 & 256439 & 52.24 \\
2 & $5-10$ & Moderately slight & 1224550 & 30.8 & 85448 & 17.81 \\
3 & $10-15$ & Moderate & 404310 & 10.4 & 59733 & 12.17 \\
4 & $15-20$ & Moderately Severe & 124280 & 3.1 & 42109 & 8.2 \\
5 & $20-40$ & Severe & 93090 & 2.3 & 33327 & 6.5 \\
6 & $>40$ & Very Severe & 3650 & 0.09 & 3649 & 0.71 \\
7 & Water bodies & 82910 & 2.2 & 10222 & 2.08 \\
\multicolumn{2}{l}{ Total Geographical Area } & 3886300 & & 510500 & \\
\hline
\end{tabular}

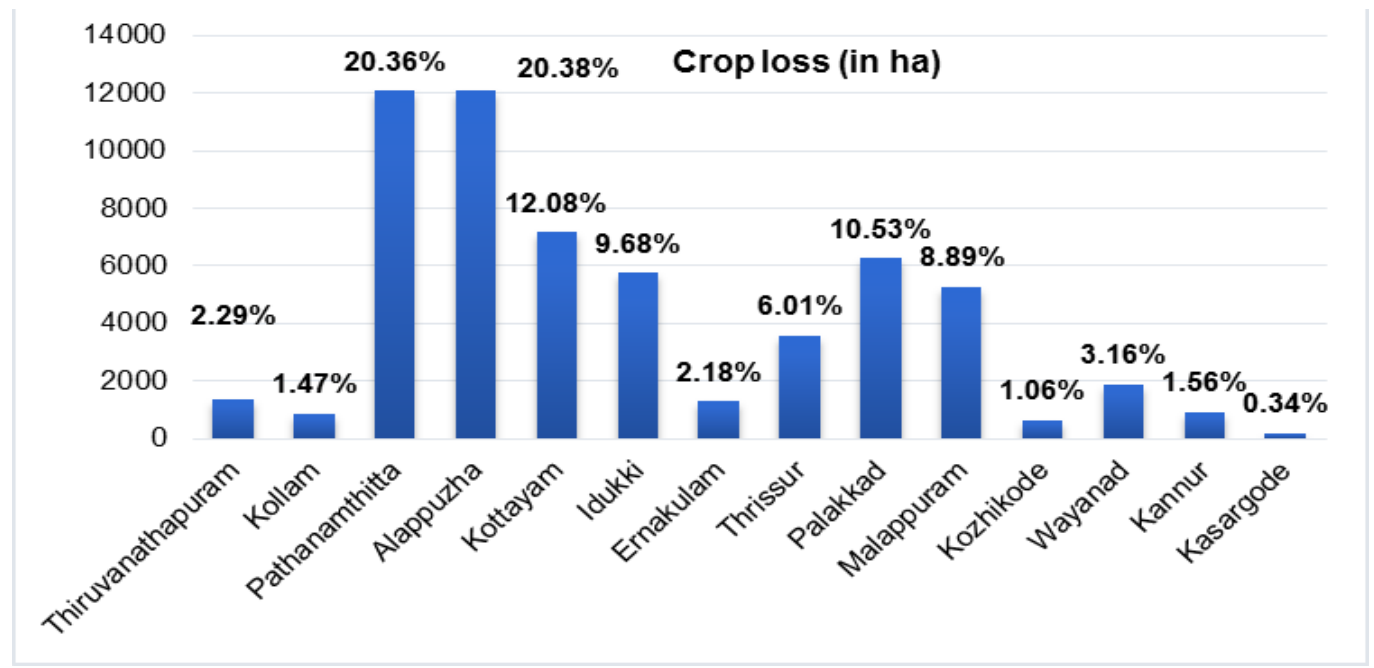

Fig. 1. District wise loss of crop area (in ha) post-flood in Kerala in 2018 (Source: GoK,2018b).

was eroded, whereas in Idukki, it was $94.16 \%$ of the total geographical area was eroded (NBSS and LUP, 2014) (Table 2). Eighty per cent of the area under soil erosion in Idukki district and that of $90 \%$ of Kerala state mainly was under the category of slight, moderately slight and moderate erosion class. About $0.74 \%$ of the area in the district was under severely eroded area, highest among the districts, where the state value was only $0.1 \%$ (Table 2 ).

Post-flood Impact in Kerala state including district Idukki: United Nations post-disaster need assessment report has estimated a total economic loss of Rs.31,000 crores in Kerala post flood. (UNEP,2019). With a total economic loss of Rs 3646 crores in the agricultural sector, over $3 \%$ of Kerala's arable land was destroyed, i.e. 40,323 ha including 25000 ha of paddy land. In addition to the agricultural sector, fisheries (93.72 crores), forestry ( 9.55 crores), infrastructure, power, housing and tourism sector (2000 crores) were also severely affected (GOK, 2018b).

Fig. 1 shows the per cent of total crop area lost to the net cropped area in the districts of Kerala during the post-flood period. DSSC (GoK, 2018a) had undertaken a study on the soil health status of Kerala in Post-flood scenario and reported that soil acidity remained as a major problem to be tackled in the post-flood scenario. More than $50 \%$ of the soils have come under the category of extremely acidic to strongly acidic, indicating the need for urgent soil reclamation measures. Widespread deficiency of available nitrogen, available potassium, Calcium, Magnesium and Boron was noticed in the sampled locations of Kerala. Deficiency of available phosphorus and zinc was also noticed in localised patches, and Zinc deficiency was noticed mainly in the valleys. 


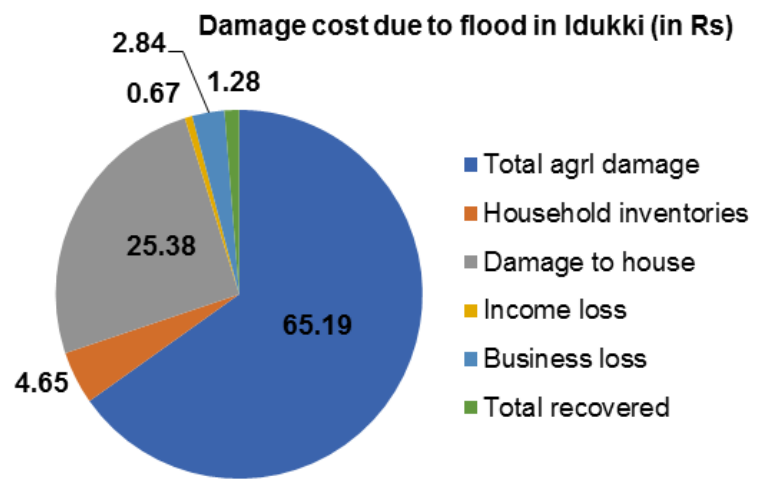

Fig. 2. Average damage cost (in Rs) in different sectors of individual household in Idukki post flood in 2018.

In case of Idukki, soil aggregation which affected agriculture by decreasing soil quality and crop production after the flood was found to be weak and a change in texture and organic matter content led to changes in the water holding capacity. Yellowing and wilting of crops, especially nutmeg, was found in the flood-affected areas. The soil $\mathrm{pH}$ had increased and acidity was reduced when compared to pre-flood data. Electrical conductivity values $(0.15$ to 0.98$)$ were found to be suitable for agricultural production, but a reduction in the fertility status of soils was found. Organic carbon (1.18 $\%$ to $3.86 \%$ ) content increased in most of the locations (mountainous, highland and upland) whereas phosphorus (4.48 to $44.8 \mathrm{~kg} / \mathrm{ha}$ ) and potassium availability ( 39.2 to $801.92 \mathrm{~kg} / \mathrm{ha}$ ) were reduced in many locations. In areas where available nitrogen, phosphorus and potassium are low, these nutrients are to be supplemented based on soil test results. Due to the changes in soil caused by landslide deposition, cultivation was not recommended in areas having slope more than $33 \%$. Soil test-based fertiliser application and adoption of proper soil conservation measures with a provision for draining-off excess water are recommended as mentioned by GOK (2018a).

Socio-economic impact due to flood in Idukki

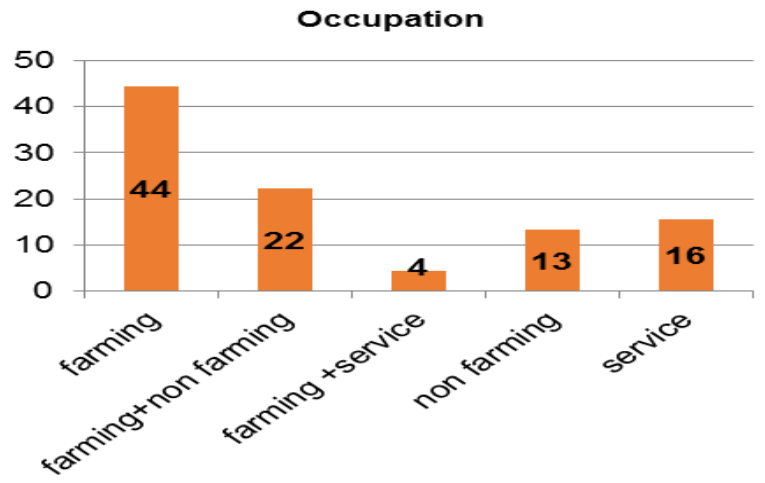

(a)

Fig. 3. Relation between (a) occupation status and (b) income generation post flood in Idukki in 2018. district: Absolute or total disaster loss/damage cost was considered as damage to agriculture, household assets or inventories, damage to house structure, income loss, business loss and repair and recovery costs. From the primary survey conducted, average damage cost (total damage costs/ number of sample households) among the 180 samples of households in Idukki district was found to be Rs.13.36 lakhs with relative loss of $364 \%$. The relative loss indicated that in Idukki, where some of the samples of households experienced entire washing off of the land, including crops and infrastructure, the households have incurred losses three times to their annual income. Relative damage cost gives an insight into the actual impact of a calamity on the livelihood of individuals. Damage to agricultural sector accounted for $65.19 \%$ of the total damage cost of the sample households followed by damage to a house property $(25.38 \%)$ and household assets $(4.65 \%)$, business loss $(2.84 \%)$, income loss $(0.67 \%)$ and total damage recovered $(1.28 \%)$ (Fig. $2)$. Damage to the agricultural sector was higher due to the loss of entire crop area due to landslides, with cropping pattern in the district including mainly perennial and plantation crops like cardamom, pepper, nutmeg, coconut, rubber etc. adding to higher crop losses too. Similarly, landslides had caused much damage to the housing infrastructure contributing to the $25 \%$ share in the total damage cost.

The results regarding income generation and percentage of damage in different sectors with respect to the total damage showed a correlation with the occupational status of the individuals surveyed. As much as $44 \%$ of the individuals surveyed were solely engaged in farming, showing lack of diversification in occupation and $29 \%$ were engaged in non-farm activities including service activities which can be related with the percentage of individuals who have not generated any income post-disaster (Fig. 3 a). Forty-eight per cent of the sample households were unable to generate in-

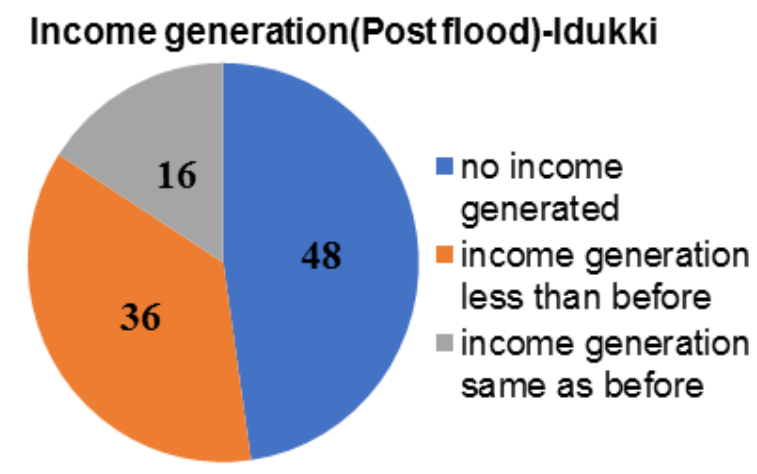

(b) 


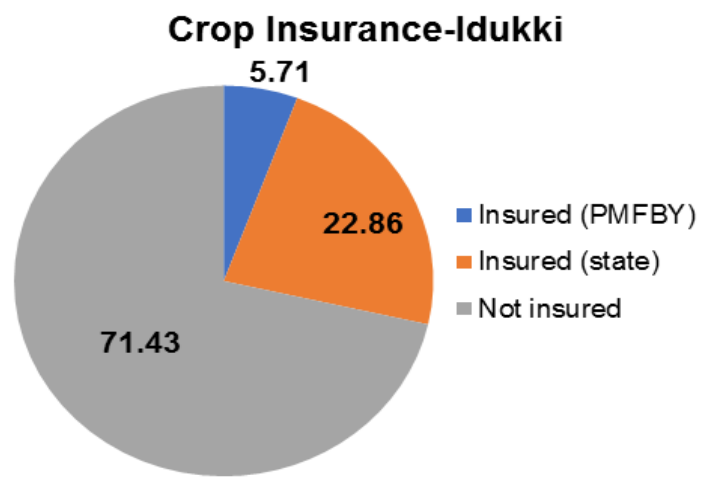

Fig. 4. Percentage of individuals in ldukki insured under different agricultural insurance schemes in 2018.

come post-disaster, and $36 \%$ could generate income which is still less than before (Fig. 3b). Lack of diversification in occupation badly affected the income generation and recovery $(1.28 \%)$ during the post-flood, i.e., individuals who only took up the farming activities suffered huge loss and no income generation when compared to individuals who have taken up other non-farm activities also. In the case of Idukki, where mostly cash crops and perennial crops were grown, $71 \%$ of the farmers had not insured their crops. Only $23 \%$ were insured under the state insurance scheme, and $6 \%$ were insured under Pradhan Mantri Fasal Bima Yojana (PMFBY) (Fig. 4).

Also, in the district, where both floods and landslides had caused huge havoc, $51 \%$ of the individuals considered shifting their residences (Fig. 5 a). Residents favouring permanent relocation may have experienced the death or injury of family members and friends or lost their homes or farmlands increasing their perception of risk. Individuals not favouring relocation may be concerned with the dilution of community ties, a dismantling of community cohesion and a breakdown of the informal social security systems. A similar response has been reported from the survivors of flash floods in Uttarakhand in 2013, where $43 \%$

(a)

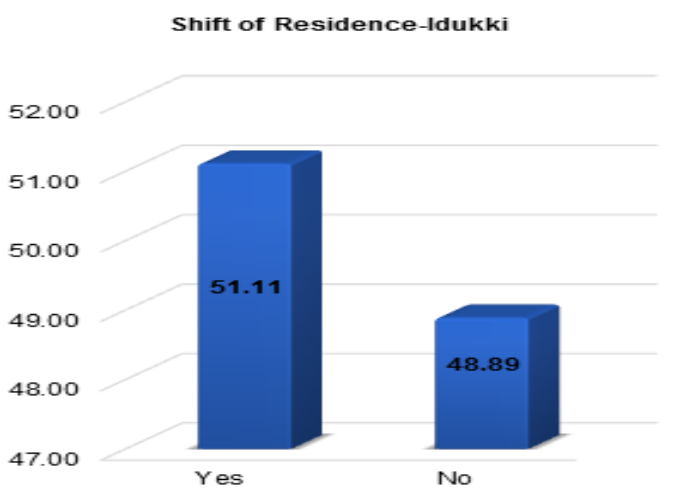

of individuals considered shifting of residence (Arlikatti et al., 2017). Asthana (2012) noted economic and socio-cultural disruption during the Tehri Dam construction in Uttarakhand where villagers forced to relocate, revolted by threatening the government with "Jal Samadhi" (i.e. selfimmolation in the river that was to submerge their village and dwellings).

Concerning the warning from government officials prior to the disaster, $31 \%$ of the individuals in Idukki, where the opening of the dams has also added to the intensity of the disaster to individuals, received no prior warning. About $58 \%$ of the individuals perceived the warning to be inadequate or unclear (Figure 5b). Considering this, the government has to ensure reviewing the existing forecasting and warning system integrating the community stakeholders. The rebuilding and recovery activities of the government should also consider individual household and community demands (Andrew et al., 2013). The government should focus not only on the structural rebuilding measures but also on the social needs of the community as a whole (Dixit, 2003).

Soil and water conservation schemes are implemented on a watershed basis in the state. Watershed selection is carried out based on one or more criteria like degradation status of arable land and drains of the area, necessity /urgency of conservation activities, priority as per watershed atlas of state land use board, the extent of agricultural area and size of holdings in the watershed, socioeconomic condition of the area, demand for undertaking watershed activities in the area, resolution from local self-government bodies, representations from farmers, inhabitants of the area etc. Stone pitched contour, and graded bund, and earthen bund etc. are some of the conservation works done in Idukki district under Rural Infrastructure Development Fund- NABARD (RIDF) and Land Slide Stabilisation programmes of Department of Soil Survey and Soil Conservation, Government of Kerala (DSSSC, GoK, 2020).

Unless supported by the government, soil conser-

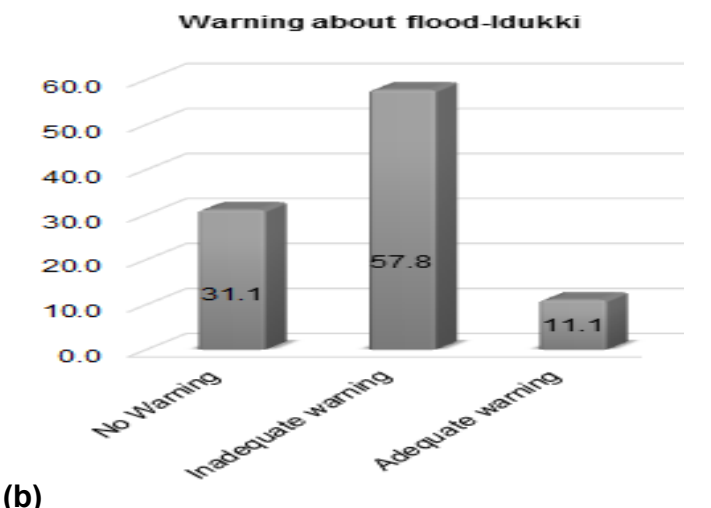

Fig. 5. Perception of individuals regarding (a) shift of residence and (b) warning about flood in 2018. 
vation activities especially erosion control through stone pitched bunds are highly expensive. Farmers often ignore the adoption of mitigation techniques because of the top-down approach of government initiatives in implementing disaster management policies and the economic constraints it put on them (Schad et al., 2012). Labour shortage and high wage rates are the main hindrances in the agricultural sector throughout the state. As the farmers in Idukki district mainly concentrate on plantation crops, especially cardamom and pepper, which are labour- and capital-intensive, farmers give less priority to the soil health status. Limitation and timely availability of funds in the concerned departments hinder authorities from taking up the soil conservation work on a large scale. Due to the need for heavy investments, individual farmers, especially, marginal, small and medium farmers, are reluctant to take up private investments. Vulnerable populations even though with risk perception, are reluctant to the adoption of conservation activities due to the psychological factor of helplessness due to economic constraint. (Lin et al., 2008) Therefore, in a district like Idukki prone to landslides, flood and erosion, public investment has to play a major role in strengthening the agricultural sector and livelihood of people.

\section{Conclusion}

On the basis of the various studies, it was indicated that in the pre-flood period of 2018, $94.7 \%$ of the total geographical area in Kerala was acidic and that of district Idukki had most of the area $(96.2 \%)$ under acidic soils among all the districts. Ninety per cent of the area under soil erosion in the Kerala state and $80 \%$ of Idukki district mainly was under the category of slight, moderately slight and moderate erosion class. The impact of flood occurred in August 2018 in Kerala, especially in Idukki district was quite sharp and economic and social consequences were high. In Idukki district, 5745.97 ha of crop area was lost. Average damage cost of individuals in different occupational status was Rs.13.36 lakhs with relative damage cost of $364 \%$. A pre-flood warning was not perceived to be adequate to reduce the extent of the damage. The study also implied perception of inadequacy in disaster warning, insurance penetration and ensuring financial aid considering the extent of damage and the economic status. Farmers in the state were reluctant to undertake soil conservation activities for combating erosion due to high labour costs and capital-intensive plantation crops in the district. Public investment has to be strengthened for sustainable agriculture and conservation of natural resources of the floodaffected areas of Kerala.

\section{REFERENCES}

1. Andrew, S. A., Arlikatti S., Long, L. C., and Kendra, J. M. (2013). The effect of housing assistance arrangements on household recovery: an empirical test of donor-assisted and owner-driven approaches. Journal of Housing and the Built Environment, 28 (1):17-34.

2. Arlikatti S., Maghelal, P., Agnimitra, N., and Chatterjee, V. (2018). Should I stay or should I go? Mitigation strategies for flash flooding in India. International Journal of Disaster Risk Reduction, 27, 48-56.

3. Asthana, V. (2012). Forced displacement: a gendered analysis of the Tehri Dam project. Economic and Political Weekly, 96-102.

4. Dixit, A. (2003). Floods and vulnerability: need to rethink flood management. In Flood problem and management in South Asia (pp. 155-179). Springer, Dordrecht.

5. DSSC (2020). Department of Soil Survey and Soil Conservation (DSSC, Government of Kerala) 2020. Retrieved from http://www.keralasoils.gov.in/ index.php/2016-04-29-09-29-18/schemes-underimplementation

6. De Silva, M. M. G. T., and Kawasaki, A. (2018). Socio-economic vulnerability to disaster risk: a case study of flood and drought impact in a rural Sri Lankan community. Ecological Economics, 152:131140

7. FAO (2019). Global Symposium on Soil Erosion. Rome, Italy, 15-17 May 2019 UN Food and Agriculture Organization (FAO)

8. GoK (2018a). Government of Kerala. Soil health status of Kerala in post flood scenario. Department of Soil Survey and Soil Conservation, Report no. 1455. Kerala, India.

9. GoK (2018b). Government of Kerala. Additional Memorandum - Kerala Floods 2018. 1st August to 30th August 2018. Department of Disaster Management. Kerala, India.

10.Lin, S., Shaw, D., and Ho, M. C. (2008). Why are flood and landslide victims less willing to take mitigation measures than the public? Natural Hazards, 44 (2): 305-314.

11.Majji, A. K., Reddy, G. O., and Sarkar, D. (2012). Acid Soils of India: Their Extent and Spatial Variability (No. 145). National Bureau of Soil Survey and Land Use Planning (NBSS and LUP).

12.Mythili, G., and Goedecke, J. (2016). Economics of land degradation in India. In Economics of land degradation and improvement-a global assessment for sustainable development. Springer, Cham. pp. 431-469

13.NBSSandLIP (2014). Soil Erosion in Kerala. National Bureau of Soil Survey and Land Use Planning, Report no.163.Nagpur, India

14.Schad, I., Schmitter, P., Saint-Macary, C., Neef, A., Lamers, M., Nguyen, L and Hoffmann, V. (2012). Why do people not learn from flood disasters? Evidence from Vietnam's north-western mountains. Natural hazards, 62(2), 221-241.

15.Stocking, M., and Murnaghan, N. (2001). Handbook for the field assessment of land degradation. Earthscan.

16.UNEP (2019). Kerala, Post-Disaster Needs Assessment: Floods and Landslides, Kerala, India 